\title{
Identification of Relationship between the Use of Mobile-based Virtual Social Networks and Critical Thinking Skills
}

\author{
Sadaf Alizadeh Derakhshi ${ }^{1}$ \\ Leila Rezaii \\ Fatemeh Razavi ${ }^{3}$ \\ Fariba Sarfaraz ${ }^{*}$ \\ 1,4Department of Educational Technology, Faculty of Psychology \& Educational Sciences \\ Allameh Tabataba'i University, Tehran, Iran \\ 2,3Department of Education Planning, Faculty of Psychology \& Educational Sciences, Allameh Tabataba'i \\ University, Tehran, Iran; *Corresponding Author: Fariba Sarfaraz, Email: sarfaraz.atu@gmail.com
}

\section{Doi:10.5901/mjss.2016.v7n1s1p259}

\section{Abstract}

\begin{abstract}
Today, scientists know the use of critical thinking skills as one of the ways of equipping students to keep pace with the fast moving world of information technology and digital media networks. The main objective of this study was to investigate the relationship between the use of virtual social skills of mobile-based and critical thinking in students Faculty of Psychology and Educational Sciences, University of Allameh Tabataba'i. Research was survey. The study population is all students of Allameh Tabataba'i University Faculty of Education and Psychology. Using simple random sampling of 100 people were chosen as samples. ANOVA of one way ANOVA was used for data analysis (ANOVA) and Tokay test to determine differences between groups. The results showed that students who use the mobile-based virtual social networks and critical thinking, and aspects of evaluation, analysis, inductive reasoning, deductive reasoning, there was no significant difference and no significant difference was observed only in the aspect of perception. Also shown there was no significant difference among the groups that are mobile-based virtual social networks with a group that did not use it. So we need to find ways to vaccinate society against new technologies in order to provide a framework for the proper use of facilities including mobile technology.
\end{abstract}

Keywords: social networks, virtual, mobile, critical thinking

\section{Introduction}

Development of science, the explosion of knowledge and the information revolution, is faced the modern world with problems whose solution is impossible without the benefit of thinking. Thinking is the process in which one tries to identify a problem that is facing and solve them using their previous experience (Farmahini Farahani and Peydad, 2010).

Due to the complexity of social, educational, economic and cultural needs of people to be able to face the surprising developments of the twenty-first century high-level thinking skills, so universities around the world are seeking ways to increase the capacity of thinking and decision-making training a non-algorithmic thinking is complex and often produces a variety of solutions.

It has been identified for various types of high-level thinking, including pointed to critical thinking. Evaluation of educational objectives developed countries shows that it is important to shape and create the right conditions for the realization of critical thinking. It is one of the most important principles in every country and every country to achieve growth and prosperity requires people with strong critical thinking. Critical thinking is considered as a basic cognitive process to grow and benefit from the knowledge and this kind of thinking is usable for development and problem solving (Maleki and Habibi pour 2007; Miri et al, 2007; Aghazadeh, 2007; Gul et al, 2010). In recent years, education experts have expressed concern about the inability of students to critical thinking. Development of intellectual skills of students in education has always been a complex issue, but today the situation has become critical because the output data has exceeded our culture of thinking critically about the information (Myers, 2007). Critical thinking is purposeful and selfjudgment that are formed as a result of the interpretation, analysis, evaluation and deduction (Akhondzadeh et al., 2011) and Emir (2009) defines critical thinking that people review all your previous knowledge in a particular subject and evaluation and their thinking skills and behavior change. Critical thinking as a thinking and judgment skills orderly, 
effective, logical, objective, and based on the outcome that arises as a result of interpretation, explanation, analysis, evaluation, inference, inductive and deductive reasoning. Features of people with critical thinking are ability receptivity to new ideas, flexibility, willingness to change, creativity, analytical, being energetic, risk, benefit from the knowledge and observer are (Jamshidian Ghale Sefidi and Khomejani Farahani, 2009; Popil, 2010). In today's world everyone needs to learn to make life just thinking critical thinking. In fact, the critical analysis of media and peer influences driving, analysis of attitudes, values, social norms and the factors affecting them and identify sources of information.

Today the connected communication technology (printing line, telephone, cinema, film, radio and television) and information technology (computers, internet and satellite) Vram have the information revolution. A group of writers know the origin of a new era of development in the world of communications; an era referred to various topics such as global village (McLuhan), global civil society (Dyd-HId), second modernity (Ulrich Beck), network society (Manuel Castells), the world abandoned (Anthony Giddens), community (Gianni Vatymv) and liquid modernity (Zygmvn Bowman) (Shahiir, 2012). Warschauer (2000) believes that today everyone can communicate with each other via the Internet, reading and writing course, only know the meaning of words and sentences grammatically correct understanding of the text or not, in today's world, the person should be equipped with critical thinking in the faced with the explosion of information on the Internet. Fans raised growing social networks as one of the important issues on the network Hara. Social networking and exciting opportunities they have attracted many viewers and fans of all ages towards its (Ahn, and Shehab, 2011).

Virtual social networks are a new generation of internet websites. In this Web sites, Internet users gather together around the same as they form a virtual community online. Social networks have depending on the activities, other facilities such as Internet feeds, online games, the ability to upload videos and personal computer files and communicate with other media as well (Ghasemzadeh, 2011). Some of the features of virtual social networks, their dynamic tools that provide users with regard to that, because people are better able to show political and religious. Some features of social networks, are: to share, mobilize and organize effect, friendship, trust, charms the audience, citing the generalization of multimedia, chat, ruthless critique, looking down and looking up, Prestige, open publishing, wisdom universality, entertainment, democratic structure, the power of social capital, social mobility, initiative and innovation (Ziaeiparvar, 2009). Mobile is one of the most popular means of communication between people and communication technology is a new era in the age of wireless communication, this means an opportunity to voice calls, short message service, multimedia messaging service-that, Dialogue Live, Play, Bluetooth, photography, video, music, location, all kinds of educational software and online news, e-books, and commercial banking services, and to facilitate human communication is easily created (Baysal et al, 2010; Westlund, 2013; Chew et al, 2013; Musa Ramezani, 2010). During the last ten years most mobile phones on a message of change in events where there were many applications to send file types without pay and only Baatsal Internet users (Bicen \& Kocakoyun, 2013). Some of these programs include the Watts-up messenger, Viber, online, credit, chatting, Bebeam, tango, the vine, Kakaotalk and so on. Social media and social networking tools, such as Viber and Watts-up software is one of the major factors in the digital world, today (Underwood, 2009; Onete et al, 2011; Yeboah \& Ewur, 2014). The networks and social media influence on the interaction of people, including the general features of this software, Viber, Tango Watts-up and exchange of information and sharing and sending and receiving messages individually or collectively, text messaging, voice, image, video and write addresses Internet (Cohavi, 2013).

According to what was said, mobile phone and its programs as a medium have a quick Artbatyrshd than other mass media and cell phone use affects all aspects of human life that people today prefer to use the phone that supports different programs and spend most of their time to use mobile capabilities such as video sharing, voice, image, text or search for information; Faced with the explosion of information technology and new process requires that users have the ability to reflect critical thinking skills in data processing, analysis and objective information and the power of good judgment and values, in the face of information.

\subsection{Objectives}

This study intends to examine the relationship between the use of mobile-based virtual social networks and critical thinking of students to determine whether the use of mobile-based virtual social networks and critical thinking about the students? The hypothesis of this study is to evaluate the use of virtual social networks based on mobile with critical thinking and analysis capabilities, inference, deductive reasoning, inductive reasoning and evaluation of students.

\subsection{Previous Research}

Sultan Alqrayy, and Suleiman Nezhad (2008) suggest that today is overtaken the amount of information available via 
computer and communications equipment the ability of the individual. In this context it is important that learners improve their skills in thinking and processing information and employ. Allah Karami (2013) did research to compare the effectiveness of Blended learning with training on creativity, critical thinking, students learn the results of this study showed that the combination is more effective than present methods on increasing creativity, critical thinking and fluid components, expansion, innovation, analysis, and understanding, but there is no significant difference between learning combined with flexibility training and evaluation components. Ali Nejad (2013) conducted a study to compare the effect on critical thinking skills and motivation smart schools and non-academic achievement of high school students in Tehran in 87-88. The results showed that the average students' critical thinking skills and intelligence higher than normal students. In research that Baba Zadeh (2009) did with title an evaluation of the relationship between information literacy and critical thinking skills students master the Faculty of Psychology and Education, University of Allameh Tabatabai results showed a significant relationship between students' critical thinking and their informational literacy. Khosrowgerdi (2007) in a study focused on the relationship between critical thinking and information-seeking behavior of their graduate students. His research results suggest that there is a significant positive relationship between critical thinking and informationseeking behavior. Agh Arkakli et al (2011) examined the impact of ICT educational applications of critical thinking attitudes of female students at the junior high school in Tehran, the results show that ICT has a significant positive effect on factors such as critical thinking, analysis, evaluation and deduction.

In addition to internal research, external research can be pointed to research Chuang (2009) in the scholarly study of the relationship between critical thinking and information literacy teachers and the impact of information technology on increasing information literacy based curriculum including The results showed that the positive relationship and there is the critical thinking skills and information literacy teachers. Rumpagaporn (2007) research on critical thinking skills and attitudes of students towards information and communication technology in computer-based classroom learning environments, has shown that levels of critical thinking increase in students and improved positive their attitude towards ICT. Allah Karami (2013) conducted a research on the assessment of problem solving and critical thinking of students using Web-based curriculum, the interdisciplinary research team of trainers created a virtual exchange that was presented students with social issues related scenarios. Each student is given a role in the scenario that portrayed their interaction with other roles (other students). They were interacting on the Internet to develop critical thinking and problemsolving skills in the virtual exchange of research-based ideas.

\subsection{The hypothesis of this study}

The general hypothesis:

The relationship between the use of mobile-based virtual social networks and critical thinking of students. Sub assumptions:

1. There is a relationship between the use of virtual social networks based on mobile and the ability to analyze the students.

2. There is a relationship between the use of virtual social networks based on mobile and capable of understanding the students.

3. There is a relationship between the use of virtual social networks based on mobile and deductive reasoning ability students.

4. There is a relationship between the use of virtual social networks based on mobile and deductive reasoning ability students.

5. There is a relationship between the uses of mobile-based virtual social networks with the ability to evaluate students.

\section{Method and Materials}

The present study is an applied and descriptive survey. The population of all students in the Faculty of Education and Psychology of Allameh Tabataba'i University who were studying in the academic year 2014-2015 Simple random sampling method in this study (100). In this study were used for statistical analysis software SPSS version 16 was used to test research hypotheses ANOVA test, one way ANOVA, the one way ANOVA test was used because of comparing an average of more than two groups, and posttest was used in order to determine the difference between the groups. 


\subsection{Research Tools}

In this study is used a questionnaire to assess critical thinking with regard to the dependent variable as follows:

The questionnaire used to measure critical thinking skills in various disciplines dedicated a lot of internal and external studies (Chen et al, 2011). California Critical Thinking is designed questionnaire in five areas of analysis, inference, evaluation, inductive reasoning and deductive. The test has 34 questions that are awarded for each correct answer, a score of one, so it will be at least a score of zero and a maximum of 34 . Up to 9 in the area of analysis, deduction, 11, 14 evaluation, inductive reasoning and deductive reasoning 16 and 14 points awarded to the person. It is also used to determine the reliability of Cronbach's alpha coefficient was the $0 / 67$.

\section{Result}

100 students participated in the study, which included 6. Group 1 less than 1 hour a week of their time was spent on virtual social networks based on the use of mobile phones, including 24 (24 percent); Group 2 was used in week one or two hours of mobile-based virtual social networks were involved in $30(30 \%)$; And Group 3 used in week two to three hours of social networks based virtual mobile were involved in $16(16 \%)$ and Group 4 weeks three to five hours of their time spent on them to participate in social networks mobile were based virtual involving 10 patients (10\%) And Group 6 not use mobile-based virtual social networks, including 13 patients (13\%).

Table 1. Results of ANOVA for comparison between groups of critical thinking and its dimensions

\begin{tabular}{|llcccc|}
\hline Variables & Total squares & Df & Mean square & $f$ & Significance level \\
\hline \multirow{3}{*}{ Evaluation } & Between group & 5 & 3.11 & 599 & 0.701 \\
& Within the group & 94 & 5.12 & & \\
& Total & 99 & & & \multirow{2}{*}{0.14} \\
& Between group & 5 & 4.34 & 1.72 & \\
& Within the group & 94 & 2.52 & & \multirow{2}{*}{0.036} \\
& Total & 99 & & & \\
Deduction & Between group & 5 & 9.07 & 2.50 & \multirow{2}{*}{0.57} \\
& Within the group & 94 & 3.62 & & \\
Educative Reasoning & Total & 99 & & & \multirow{2}{*}{0.98} \\
& Between group & 5 & 5.86 & & \\
Weasoning & Within the group & 94 & 5.96 & & \\
Total & 99 & & & \\
Inductive & Between group & 5 & 15.48 & 0.79 & \\
& Within the group & 94 & 20.74 & & \\
& Total & 99 & & & \\
\hline
\end{tabular}

According to Table 1, there was no significant association between the use of mobile-based virtual social networks and critical thinking and the ability of inductive reasoning, deductive reasoning, analysis, evaluation of the level of 0/05)> (siq but significant relationship respectively. The perception in the (siq <0/05), as well as to answer the question of whether there is a significant difference between the groups of virtual social networks on mobile phones, and those who do not use it, and critical thinking, its capabilities, Tukey test was used, significant differences were observed in the test groups of virtual social networks on their mobile phones, including groups $(1,2,3,4,5)$ would be superior to those virtual social networks on mobile phones did not (group 6) in terms of critical thinking and its dimensions.

\section{Discussion}

In an era when called density and reproduction of information (Information Pollution Era), the amount of knowledge and information is provided through a variety of computer and communications equipment, has overtaken the ability of individuals to use them as well as all of the information according to have the critical thinking of ways to keep their dynamics over time.

As was observed (Table 1) there was no significant difference between the dimensions of critical thinking, evaluation, analysis, inductive reasoning, deductive reasoning, students who used mobile-based virtual social networks and those who do not use, but a significant relationship There was the understanding between the use of mobile-based 
virtual social networks and the ability to elicit students.

Unfortunately, there is no research on the subject, but the results of research controversial Ali Nejad (2013), Baba Zadeh(2009), Khosrowgerdi and Jahromy (2007), Chuang (2009), Rumpagaporn (2007), as well as the inferred research findings align with research Agh Arkakli et al (2011) but did not align with other potential inductive reasoning, deductive reasoning, analysis, evaluation of critical thinking as well as Along with the release of Allah Karami's study (2013) on the evaluation and deduction, but not aligned in the analysis .

The lack of alignment of Comparative Effectiveness Analysis findings Blended learning and training students in critical thinking, creativity, free, Allah Karami (2013) showed that the most effective learning combined with face to face method on increasing creativity, thinking critical fluid components, expansion, innovation, analysis, and understanding, but there is no significant difference between learning combined with flexibility training and evaluation components. The results of this study were not consistent in explaining the dimensions of analysis, can be executed because of his role as test and can affect classmates and their impact on each other to increase the critical thinking, study of the students and while wrought Teachers and classmates had no part in it.

When a new technology such as mobile phone market, we have never encountered such an issue Since the liver is not their strategies to vaccinate against it; Thus, the formation of a technology culture needs the culture and history of personal, intellectual, social and family each person, as people according to their individual culture can be true or false use of a new technology.

Factors that could affect in the absence of a significant relationship between the use of mobile-based virtual social networking skills and deductive reasoning, inductive reasoning, analysis, assessment, students are mobile for entertainment and leisure and weaknesses analysis and evaluation skills training, content, text, images, audio, and video that can be shared on social networks based virtual mobile.

\section{References}

Agh Arkakli R, Safari N, Hafezi Kan Kowt H. (2011). Surveying the Effect of Educational Applications of Information and Communication Technology on the Critical Thinking and Attitude of the First Grade High School Girl Students from District 4 in Tehran. Journal of in Research Curriculum Planning 8(4): 36-49

Aghazadeh, A. (2007). Comparative Education. Tehran: Payame Noor University Publication.

Ahn, G. J., Shehab, M., \& Squicciarini, A. (2011). Security and privacy in social networks. Internet Computing, IEEE, 15(3), 10-12.

Akhondzadeh K, Ahmari Tehran H, Salehi S, \& Abedini Z. (2011). Critical thinking in nursing education in Iran. Iranian Journal of Medical Education. 11(3): 210-221

Ali Nejad, M. (2014). The relationship between information literacy and critical thinking. First National Conference on Sustainable Development in Education and Psychology, Social and Cultural Studies.

Allah Karami, A, (2013). Blended learning and training than on creativity and critical thinking holy city high school students. MA dissertation. Allameh Tabatabaei University.

Baba Zadeh, M. (2009). The relationship between information literacy and critical thinking skills students master the Faculty of Psychology and Educational Sciences of Allameh Tabatabai University. MA dissertation. Allameh Tabatabaei University.

Baysal, Z. N., Şahenk, S. S., \& Hazneci, Y. Ö. (2010). Evaluation of the primary school level students' attitudes towards mobile phones. Procedia - Social and Behavioral Sciences, 2(2), 4279-4284. doi:10.1016/j.sbspro.2010.03.679

Bicen, H., \& Kocakoyun, S. (2013). The Evaluation of The Most Used Mobile Devices Applications by Students. Procedia - Social and Behavioral Sciences, 89, 756-760. doi:10.1016/j.sbspro.2013.08.928

Chen, S.-L., Liang, T., Lee, M.-L., \& Liao, I.-C. (2011). Effects of Concept Map Teaching on Students' Critical Thinking and Approach to Learning and Studying. J Nurs Educ, 50(8), 466-469. doi:10.3928/01484834-20110415-06

Chew, H. E., Ilavarasan, P. V., \& Levy, M. R. (2013, December). When there's a will, there might be a way: the economic impact of mobile phones and entrepreneurial motivation on female-owned microenterprises. In Proceedings of the Sixth International Conference on Information and Communication Technologies and Development: Full Papers-Volume 1 (pp. 196-204). ACM. doi.org/10.1145/2516604.2516605

Chuang, J. (2009). The relationship between junior higher school teacher's critical thinking skills with information literacy and their integration of information technology into curriculum in Taiwan. Doctoral Thesis. Spalding University.

Cohavi, A. (2013). How did Whatsapp became the strongest social network? Calcalist. Retrieved from http://www.calcalist.co.il/local/ articles/0,7340,L-3593840,00.html

Emir, S. (2009). Education faculty students' critical thinking disposition according to achedemic achievement. Procedia - Social and Behavioral Sciences, 1(1), 2466-2469. doi:10.1016/j.sbspro.2009.01.433

Farmahini Farahani, M., Peydad, F. (2010). Life skills. Tehran: Shabahang.

Ghasemzadeh, M. (2011). The role of social networks in regional and international developments. Portals of our policy, public diplomacy and media.

Gul, R., Cassum, S., Ahmad, A., Khan, S., Saeed, T., \& Parpio, Y. (2010). Enhancement of critical thinking in curriculum design and 
delivery: A randomized controlled trial for educators. Procedia - Social and Behavioral Sciences, 2(2), 3219-3225. doi:10.1016/j. sbspro.2010.03.491

Jamshidian Ghale Sefidi, T., and Khomejani Farahani, AA. (2009). The relationship between native language, gender, age and level of critical thinking. Journal of Foreign Languages, 55:71-86.

Khosrowgerdi M, Jahromy, RG (2007). Relationship between Critical Thinking graduate students with their information-seeking behavior. Atelashenasy 5 (1 and 2): 134-155.

Maleki, H. and Habibi Pour, M. (2007). The main purpose of education fosters critical thinking. Journal of Educational Innovations, 6(19): 14-25.

Miri, B., David, B.-C., \& Uri, Z. (2007). Purposely Teaching for the Promotion of Higher-order Thinking Skills: A Case of Critical Thinking. Research in Science Education, 37(4), 353-369. doi:10.1007/s11165-006-9029-2

Musa Ramezani, S. (2010). The effects of training methods on learning, retention and achievement motivation Arabic language students of distance learning centers in Tehran. MA Dissertation, Faculty of Education and Psychology, Allameh Tabatabai University.

Myers, Ch (2007). Teaching critical thinking (translated by Khodayar Abili, Seventh Edition). Tehran: SAMT.

Onete, C. B., Dina, R., \& Negoi, E. R. (2011). Estimating the Importance of Social Media in Consumers' education and Information Using New Techniques. The Amfiteatru Economic Journal, 13(5): 736-745.

Popil, I. (2011). Promotion of critical thinking by using case studies as teaching method. Nurse Education Today, 31(2), 204-207. doi:10.1016/j.nedt.2010.06.002

Rumpagaporn, W.M. (2007). Students Critical Thinking Skills, Attitudes to ICT and Perceptions of ICT Classroom Learning Environments under the ICT Schools Pilot Project in Thailand. PHD thesis, University of Adelaide.

Shahiir, E. (2012). Identify external factors to the virtual social networks studied social network users. MA Dissertation. Tehran University.

Sultan Alqrayy, Kh, Suleiman Nezhad, A. (2008). Critical thinking and teaching them in the classroom. Journal of Islamic education, 6:32-46.

Underwood, J. D. (2009). The impact of digital technology: a review of the evidence of the impact of digital technologies on formal education. UK: British Educational Communications and Technology Agency (BECTA).

Warschauer, M. (2000). The Changing Global Economy and the Future of English Teaching. TESOL Quarterly, 34(3), 511. doi: $10.2307 / 3587741$

Westlund, O. (2013). Mobile news: A review and model of journalism in an age of mobile media. Digital Journalism, 1(1), 6-26. doi:10.1080/21670811.2012.740273

Yeboah, J., \& Ewur, G. D. (2014). The impact of whatsApp messenger usage on students' performance in Tertiary Institutions in Ghana. Journal of Education and practice, 5(6), 157-164.

Ziaeiparvar., H. (2009). Virtual social networking features. Strategic Research Center. 